\title{
Catastrophic Asia: An Introduction
}

\section{TIM OAKES}

$\mathrm{C}_{\mathrm{a}}$ atastrophic Asia began as an experimental initiative of the Center for Asian Studies at the University of Colorado Boulder. Culminating in a spring 2014 symposium where three of the four papers presented here and earlier versions of the two commentaries were delivered, the project sought to bring together a diversity of perspectives on Asian experiences of and vulnerability to disasters. We sought to collect an unlikely group of scholars whose work is not typically discussed in a single forum. They included natural and physical scientists, anthropologists, geographers, and scholars of literature. The project sought to discover what common epistemological ground might be found when such diverse approaches are brought to bear on catastrophic events, as well as the risks of catastrophe, in a particular area of the world.

The papers collected here represent the work of two anthropologists (Bridget Hanna, on the toxic legacies of the Union Carbide disaster in Bhopal, and Magdalena Stawkowski, on the social lives of radioactive commodities produced at the Soviet-era nuclear test site of Semipalatinsk in Kazakhstan), a team of atmospheric physicists (Owen B. Toon et al., on risks and potential effects of a nuclear war in Asia), and a team of hydrologists (Alana Wilson et al., on the water security implications of climate change in "High Asia"). These are followed by commentaries from anthropologist Donna Goldstein and geographer Emily Yeh. Some of these contributors will not be recognized as "Asianists" in the traditional sense of the term (indeed, Goldstein's area of expertise is Latin America). Such was the experimental nature of Catastrophic Asia that we felt compelled to break away from the standard academic collectives to find out what new conversations might be had.

In some respects, Catastrophic Asia parallels and extends a conversation begun at a 2014 JAS at AAS Roundtable: "Asian Studies and Human Engagement with the Environment." Collected as a special section in this journal (Journal of Asian Studies 73(4), 2014), archaeologist Mark Hudson's exploration of the significance of the Anthropocene to Asian studies was followed by responses by religious studies scholar Johan Elverskog, historian of science Kavita Philip, literature specialist Karen Thornbe, journalist and editor Isabel Hilton, and anthropologist Gene Ammarell.

Hudson $(2014,943)$ argues that research on global environmental change requires "new, inter- and trans-disciplinary approaches." Yet he finds that the Anthropocene offers significant challenges to Asian area studies, given the former's global, unbounded scale and the latter's history of rather parochial scholarship (my term, not his). In addition to a reluctance to write about Asia explicitly within broader global contexts, Asianists, he 
finds, have been slow to adopt new ideas that problematize the nature-culture binary. In the end, he argues that Asianists can contribute "our understanding of the local contextualization of systems of adaptive learning" and provide case studies "of long-term strategies for sustaining diversity, memory, and crisis response within Anthropocene social-ecological systems" (955).

Hudson's intervention and his panelists' responses offer an important call for not just the importance of interdisciplinary — and transdisciplinary—work on large-scale, complex topics like global climate change, but also the specific contribution of Asian area studies to this broader academic project. Articulating what that contribution actually looks like, however, remains a significant-though necessary-challenge in Asian studies. Climate change seems to be the area of study that has garnered the most interest in the context of existing scholarship on Asian experiences of, vulnerabilities to, and resilience in the face of disasters. In the past few years, studies have confirmed the increasing frequency and intensity of climate-related events, and found that Asia hosts a disproportionate share of the impacts and costs of these events (Freeman and Green 2010; Vinod 2014). For example, with some 60 percent of the world's population, Asia accounted for 85 percent of the global population killed or displaced by "natural" disasters in 2011 (Islam and Lim 2015). In 2013 alone, over nineteen million people in Asia were displaced by weather-related disasters, representing the majority of the world's affected population (Singer and Price 2016). As with Hudson, most of this work argues that understanding and mitigating the impacts of climate-induced disasters requires innovative, multidisciplinary approaches-meaning an integration of humanities and social science approaches with climate science-though area studies is rarely mentioned explicitly in this context (cf. Nisbet et al. 2010; Palsson et al. 2013). This lacuna is noted by Philip (2014), who argues in her response to Hudson's paper that if more area studiesbased humanists and social scientists were active in global climate discussions, putting those discussions more meaningfully within the place-based contexts in which they work, then perhaps those discussions would be less likely to "run aground" politically as they typically have done. Such a discussion, she notes, requires, however, that area studies scholars reject the disciplinary confines within which they comfortably work.

Catastrophic Asia's focus is less on climate change-related disaster (though that remains the topic of the paper by Wilson et al. on the vulnerability of "High Asia" to climate change). Three of the four collected studies here are instead about more direct forms of human-induced disaster (toxic spills, nuclear war, and radioactive waste). Our objective from the beginning was to push beyond the disciplinary comfort zones that Philip sees as inhibiting the true promise of the area studies approach. Our objective has also been to encourage a discussion of disasters that pushes well beyond the management and policy focus that dominates current research on catastrophic events in Asia (see, e.g., Butt, Nasu, and Nottage 2014; Ha, Fernando, and Mahmood 2015; Jha and Stanton-Geddes 2013; Kusakabe, Shrestha, and N 2015; Wang et al. 2013).

While work on disaster management and mitigation helps us understand some of the unique vulnerabilities that Asia's populations face-such as rapid urbanization and uncoordinated development that has outstripped infrastructural capacities; relatively weak legal and regional cooperation institutions; or pronounced ethnic, racial, religious, and class divisions that inhibit comprehensive policy implementation-much of this work could still benefit from the kinds of historical and cultural contextualizing that area 
studies scholars can bring. Recent work emerging from the National University of Singapore Asia Research Institute’s (ARI) “Disaster Governance” research cluster represents a welcome step in this direction (see, e.g., Miller and Douglass 2015, 2016). The ARI project has taken a broad approach to governing, and has focused on the challenges facing Asia's rapidly urbanizing societies in an era of increasingly frequent and intense weather events. The Disaster Governance project makes clear that addressing these complex social and atmospheric processes requires innovative interventions beyond the policy recommendations and technical fixes that one tends to find in the executive summaries of disaster management and mitigation reports. Extending from this insight, we approached Catastrophic Asia as an effort to find potentially innovative interventions in the transdisciplinary conversations between area specialists and environmental scientists.

As readers will readily discover in the papers and commentaries that follow, a key tension pervades the entire project of Catastrophic Asia. In our attempt at a transdisciplinary conversation, we found ourselves running up against a perennial area studies question: what, if anything, is gained by exploring the universal theme of disaster from the arguably arbitrary perspective of one particular area of the globe? To what extent does the "Asianness" of catastrophe matter? On the one hand, catastrophe has been on the minds of Asianists a great deal over the past few years. This is no doubt due, in part, to the triple-catastrophe of March 11, 2011: the Tohoku earthquake, tsunami, and nuclear crisis at Fukushima. But to this we could add a whole list of morbid events: the Sichuan earthquake of 2008, "superstorm” Haiyan's devastation of the Philippines in 2013, China's chronic "airpocalypse" conditions that have been compared to a "nuclear winter," recent flooding in Myanmar and Bangladesh (and China and Indonesia), the eruption of Mt. Ontake, and the slow-motion catastrophe that sea-level rise promises to bring to billions of vulnerable Asians. The list could go on, but at some point the impulse to account for such catastrophes in Asia becomes a dubious project of propping up, once again, the distinctness and even separateness of a unique swath of the Earth known as "Asia," rendering it a coherent and meaningful object of study (cf. Oakes 2009). There is nothing particularly compelling about the fact that Asia hosts its share of disaster, suffering, and misery. To consider the Asian dimensions of catastrophe, then, is to risk neglecting the fundamental fact that all humans are biophysically vulnerable to disaster in the same ways, no matter where they live.

Nevertheless, themes of Asian disaster, risk, and vulnerability have been prominent recently among various Asia-based research venues, such as ARI's Disaster Governance project already mentioned. The year 2014 saw a burst of disaster-related projects in the Asian academy, including Ateneo de Manila University's conference on disasters in historical and comparative perspective and the University of Kerala's conference on "Disaster, Risk, and Vulnerability." The 2014 Pritzker Award-the top international architectural prize-went to Japanese architect Shigeru Ban, largely because of his work designing temporary shelters for natural disaster victims in Japan, China, India, New Zealand, Haiti, Turkey, and Rwanda. That same year, in addition to our own Catastrophic Asia symposium, Columbia University hosted a conference on "Catastrophe and Aesthetics: The Arts after Fukushima.” And Ted Bestor's 2013 Presidential Address to the Association for Asian Studies explored the "cultural biographies of disasters," considering in insightful and provocative ways how catastrophes can be viewed as 
cultural events with their own biographical trajectories that shape cultural landscapes; senses of place; and collective memories, values, and senses of morality for generations (Bestor 2013).

Catastrophic Asia thus emerged during what seems to be an intellectual shift of sorts: a focus on the "Asianness" of catastrophe, in which it is increasingly noted by scholars and popular media pundits alike that Asia is disproportionately vulnerable to disaster (WHO 2014), that its risk of catastrophe somehow brings Asia to the foreground of discussions of global problems associated with, for example, climate change, sea-level rise, and rising toxicity.

Wary of embarking on an intellectual project that might once again separate "Asia" out as a distinct Other characterized by essential a priori difference, and also recognizing that the complex forces shaping disasters in Asia are often themselves global in nature, we wanted Catastrophic Asia to ultimately focus less on the Asian dimensions of disaster, and more on what catastrophe teaches us about the limitations and potentials of the whole Asian studies field. In her commentary, Emily Yeh drives this point home by noting that this collection of papers helps us shift the question "from the now-tired 'What do we mean by Asian studies?' to 'What is Asian studies?'” What tools, in other words, do Asianists - as area studies specialists — use that might help bring about a truly transdisciplinary conversation across the humanities, social, and natural and physical sciences?

In our current moment of increasing fiscal challenges for area studies in US academic institutions (in which, for example, federal international and foreign language education funding through Title VI Resource Centers and Fulbright-Hays grants has been cut severely), area studies programs are being encouraged to partner with fields-for example, science, technology, engineering, and math—where resources are more plentiful. University administrators, in efforts to stretch shrinking budgets, have encouraged area studies centers to make their services as content providers available to research teams whose funders, such as the National Science Foundation, are themselves looking for more multidisciplinary conversations across the social, natural, and physical sciences. Unfortunately this has had the tendency to reinforce, rather than break down, the epistemological walls that separate disciplines, since area studies is often reduced to a subcontractor role within projects whose broader intellectual framings remain firmly ensconced within existing scientific paradigms.

This is where the dynamic nature of disaster offers an important opportunity for intervention. As Goldstein makes clear in her commentary, the experience of risk, and its multiple facets, can be a tremendously useful way of connecting fields of study that seemingly have little common ground otherwise. And the biophysical immediacy of catastrophe makes a good case for why finding such common ground is necessary. Disasters tend to make clear the failings of those disciplinary divides that Philip (2014) has encouraged area studies scholars to continue pushing beyond, for they require a framework that brings together, rather than separates, the human and the nonhuman, the cultural and the natural. Disasters require that we understand the material properties of our world in ways that are not only about cultural meaning and social organization but also about physics or chemistry. The current debates swirling around ideas of the posthuman (Wolfe 2009), of new materialism (Coole and Frost 2010), and actor-networks (Law and Hassard 1999) have yet to see a significant impact in conversations about the direction of area studies scholarship. 
As the "material turn" makes its way through the humanities and social sciences, we are perhaps becoming better equipped, theoretically, to produce accounts that assemble the diverse human and nonhuman actors (or "actants," as we may want to call them) necessary for transdisciplinary analysis. There is, by now, a clear willingness to question the coherence and separateness of "the social" from a broader realm of nonhuman phenomena. As summarized by Bennett and Joyce $(2010,4)$, this turn away from a coherent social totality suggests "the erasure of familiar conceptual distinctions between the natural and the social, the human and the non-human, and the material and the cultural, divisions that are all in the first place predicated on the immaterial/material divide." They go on to propose that we view the social as "performed by material things just as much as by humans, so that labeling one thing a person and one a machine, one thing material and one thing not, is not given in the order of things but is itself a product of the ordering of people and things that make up the social in the first place" (see also Anand 2015; Appadurai 2015; Bennett 2010; Whatmore 2006).

Such an ontological "flattening" of our tendency to privilege the social (cf. Deleuze and Guattari 1987) is perhaps what catastrophic events can compel us to work toward in responding to Philip's call to push beyond our disciplinary comfort zones. Catastrophic events bring into sharp focus the folly of separating our social lives from the dynamic biophysical materiality of our world. As a whole, the papers collected here grapple with the political implications of knowledge that strives to work against those "familiar conceptual distinctions between the natural and the social." The papers make clear the need for political action based on a more holistic understanding of the human and nonhuman worlds, one in which the conventional epistemological divide between "science" and "society" is obliterated (Latour 2014).

Given that the disciplinary orientations of the four papers in the collection remain clearly visible, the papers do not themselves reach the level of a new transdisciplinary paradigm. The heavy lifting of drawing the papers together into conversation on science, politics, and the potential of area studies for a transdisciplinary intervention is done by our two commentators. Their critiques and analyses suggest how the collection, despite its shortcomings in crossing epistemological frontiers, does present a compelling case not only for why a transdisciplinary approach is needed and worth pursuing, but more importantly for what such a conversation might look like. As a whole, the collection also presents a case for why Asianists should consider themselves well-suited for such a conversation.

The Catastrophic Asia project straddles a tension between a focus on Asia as a particular site of catastrophe and a focus on catastrophe as a topic capable of transcending entrenched epistemological divides. That tension meets in the ongoing reevaluation of the area studies project. It is our hope that these papers and commentaries stimulate some important new steps toward resolving this tension with an impetus for a truly transdisciplinary area studies field.

\section{Acknowledgments}

Funding for the Catastrophic Asia Symposium was generously provided by the Office of the Vice Chancellor for Research and the College of Arts and Sciences at the 
University of Colorado Boulder. Thanks also to the other participants in the symposium, including Waleed Abdalati, Carla Jones, Jerry Peterson, and Laurel Rodd. Finally, many thanks two anonymous reviewers who helped improve this introduction as well as the collection as a whole, and to Jeff Wasserstrom for his steadfast encouragement.

\section{List of References}

Anand, Nikhil. 2015. "Leaky States: Water Audits, Ignorance, and the Politics of Infrastructure." Public Culture 27(2):305-30. doi:10.1215/08992363-2841880.

Appadurai, Arjun. 2015. "Mediants, Materiality, Normativity." Public Culture 27(2): 221-37. doi:10.1215/08992363-2841832.

Bennett, Jane. 2010. Vibrant Matter: A Political Ecology of Things. Durham, N.C.: Duke University Press.

Bennett, Tony, and Patrick Joyce, eds. 2010. Material Powers: Cultural Studies, History, and the Material Turn. London: Routledge.

Bestor, Theodore. 2013. "Disasters, Natural and Unnatural: Reflections on March 11, 2011, and Its Aftermath.” Journal of Asian Studies 72(4):763-82.

Butt, Simon, Hitoshi Nasu, and Luke Nottage, eds. 2014. Asia-Pacific Disaster Management: Comparative and Socio-Legal Perspectives. Heidelberg: Springer.

Coole, Diana, and Samantha Frost, eds. 2010. New Materialisms: Ontology, Agency, and Politics. Durham, N.C.: Duke University Press.

Deleuze, Gilles, and Felix Guattari. 1987. A Thousand Plateaus: Capitalism and Schizophrenia. Translated by Brian Massumi. Minneapolis: University of Minnesota Press.

Freeman, Charles, and Michael Green. 2010. Asia's Response to Climate Change and Natural Disasters: Implications for an Evolving Regional Architecture. Washington, D.C.: Center for Strategic and International Studies.

Ha, Huong, R. Lalitha S. Fernando, and Amir Mahmood, eds. 2015. Strategic Disaster Risk Management in Asia. New Delhi: Springer.

Hudson, Mark. 2014. "Placing Asia in the Anthropocene: Histories, Vulnerabilities, Responses." Journal of Asian Studies 73(4):941-62.

Islam, MD Saidul, and Si Hui Lim. 2015. "When 'Nature' Strikes: A Sociology of Climate Change and Disaster Vulnerabilities in Asia." Nature and Culture 10:57-80.

Jha, Abhas Kumar, and Zuzana Stanton-Geddes, eds. 2013. Strong, Safe, and Resilient: A Strategic Policy Guide for Disaster Risk Management in East Asia and the Pacific. Washington, D.C.: World Bank.

Kusakabe, Kyoko, Rjendra Shrestha, and Veena, N, eds. 2015. Gender and Land Tenure in the Context of Disaster in Asia. Heidelberg: Springer.

Latour, Bruno. 2014. Politics of Nature: How to Bring the Sciences into Democracy. Cambridge, Mass.: Harvard University Press.

Law, John, and John Hassard, eds. 1999. Actor Network Theory and After. London: Blackwell.

Miller, Michelle Ann, and Mike Douglass. 2015. "Governing Flooding in Asia’s Urban Transition." Pacific Affairs 88(3):499-515.

—. eds. 2016. Disaster Governance in Urbanising Asia. Singapore: Springer.

Nisbet, Matthew C., Mark A. Hixon, Kathleen D. Moore, and Michael Nelson. 2010. "Four Cultures: New Synergies for Engaging Society on Climate Change." Frontiers in Ecology and the Environment 8(6):329-31. 
OAKes, Tim. 2009. “Asia.” In The International Encyclopedia of Human Geography, Volume 1, eds. Rob Kitchen and Nigel Thrift, 214-19. Oxford: Elsevier.

Palsson, Gisli, Bronislaw Szerszynski, Sverker Sörlin, John Marks, Bernard Avril, Carole Crumley, Heide Hackmann, Poul Holm, John Ingram, Alan Kirman, Mercedes Pardo Buendia, and Rifka Weehuizen. 2013. "Reconceptualizing the 'Anthropos' in the Anthropocene: Integrating the Social Sciences and Humanities in Global Environmental Change Research." Environmental Science and Policy 28:3-13.

Philip, Kavita. 2014. "Doing Interdisciplinary Asian Studies in the Age of the Anthropocene." Journal of Asian Studies 73(4):975-87.

Singer, Jane, and Susanna Price, eds. 2016. Global Implications of Development, Disasters, and Climate Change: Responses to Displacement from Asia Pacific. London: Routledge.

Vinod, Thomas. 2014. "Confronting Climate-Related Disasters in Asia and the Pacific." Jahrbuch für Wirtschaftswissenschaften 65(2):121-35.

Wang, Fawu, Masakatsu Miyajima, Tonglu Li, Wei Shan, and Teuku Faisal Tachani, eds. 2013. Progress of Geo-Disaster Mitigation Technology in Asia. Heidelberg: Springer.

Whatmore, Sarah. 2006. "Materialist Returns: Practising Cultural Geography in and for a More-Than-Human World." Cultural Geographies 13(4):600-609.

WHO (World Health Organization). 2014. "7 Million Premature Deaths Annually Linked to Air Pollution." http:/www.who.int/mediacentre/news/releases/2014/airpollution/en/ (accessed March 25, 2014).

Wolfe, Cary. 2009. What Is Posthumanism? Minneapolis: University of Minnesota Press. 